\title{
Two cultures, one identity: formulations of Australian Isma'ili Muslim identity
}

\author{
Karim Mitha ${ }^{1,2,3,4}$ (D) Shelina Adatia ${ }^{5}$. \\ Rusi Jaspal ${ }^{6,7}$
}

Published online: 9 March 2017

(C) The Author(s) 2017. This article is published with open access at Springerlink.com

\begin{abstract}
The Shi'a Imami Nizari Isma'ili Muslims have often been considered the "poster child" for pluralistic integration (Cayo 2008). This ethos has been inculcated within members of the community, with its adherents seeing themselves as a diverse and multi-ethnic collective. Nevertheless, despite this purported pluralism, social research on the Isma'ilis has primarily focused on the diasporic and post-diasporic migrant communities of South Asian descent, the 'first and second-generation immigrants,' in the Euro-American context (Mukadam and Mawani 2006, 2009; Nanji 1983, 1986). The experiences of co-religionists in other contexts have often been neglected. This study examines how members of the self-described geographically and socially isolated Isma'ili community in Australia construct their identity vis-à-vis the larger, global, Isma'ili community, and how they have responded to the potential of identity threat given the arrival of another group of Isma'ilis with a differing migratory history integrating into the extant community. Using the approach of identity process theory, this study examines how salient features of identity are constructed amongst the
\end{abstract}

Karim Mitha

k.mitha@sms.ed.ac.uk

1 Edinburgh Migration, Ethnicity, and Health Research Group (EMEHRG), Centre for Population Health Sciences, Old Medical School, Teviot Place, University of Edinburgh, Edinburgh, UK

2 Department of Clinical and Health Psychology, School of Health in Social Sciences, Old Medical School, Teviot Place, University of Edinburgh, Edinburgh, UK

3 Department of Psychology, 7 George Square, University of Edinburgh, Edinburgh, UK

4 Alwaleed Centre for Islam in the Contemporary World, 16 George Square, University of Edinburgh, Edinburgh, UK

5 Faculty of Education, 75 Laurier Avenue East, University of Ottawa, Ottawa, Canada

6 Department of Psychology, School of Applied Social Sciences, Faculty of Health and Life Sciences, The Gateway, De Montfort University, Leicester, UK

7 Mary Seacole Research Centre, The Gateway, De Montfort University, Leicester, UK 
Australian Isma'ilis, how religion and identity take on multiple meanings within the Australian Isma'ili context, and, finally, sheds light on the self-sufficiency of this community despite geographic and social isolation.

Keywords Muslim · Australia · Identity process theory · Religion · Community · Social psychology

\section{Introduction}

Islam is often essentialised as a homogeneous monolithic religious entity without recognition of the great diversity underpinning the various Muslim traditions. Indeed, popular models of Islam, particularly amongst diasporic Muslim communities, tend to adhere to a "constructed" form of the religion - one which neglects local cultural syncretism whose adherence to a global ummah can vary. This paper specifically examines the Australian Isma'ili Muslim community, which, as a small minority within a minority, has been overlooked both within the academic sphere, and, arguably, within the broader Isma'ili and Muslim societies.

\section{The Isma'ilis - their history, migration, and identity}

Of the world's 1.6 billion Muslims, approximately $10 \%$ are Shi'a. They believe that temporal and spiritual leadership of the Muslim ummah, following the death of Prophet Muhammad, continued through genealogical succession through the House of the Prophet (Ahl al-bayt) by divine ordination (nass). The early Shi'a community split in the eighth century AD/second century AH into the Ithna'Asharis and the Isma'ilis ${ }^{1}$ due to a succession crisis of leadership. The Isma'ilis affirm that the imamate (leadership) has continued to this day and regard Aga Khan IV as their 49th Imam (Daftary 1998; Versi 2010). Today, the Isma'ilis are a multi-ethnic community living in approximately 25 countries, though are largely concentrated in Central and South Asia, Africa, and the Middle East, with large numbers in North America and Europe (Daftary 1998).

Critical junctures in the community's migratory history have directly impacted construction of its identity, from batiniyya (esotericists) during the Fatimid Caliphate to living in taqiyya (dissimulation) after the fall of Alamut in $1256 \mathrm{AD} / \sim 655 \mathrm{AH}$. It is postulated that this practice of taqiyya helped the Isma'ilis to subsequently integrate into their various host nations. The revival of "Isma'ili identity" stemmed from the migration of the 46th Imam, Aga Khan I, from Iran to India in the mid-19th century which caused a re-formulation of Satpanthi Khojas and their traditions to become more ensconced within an Islamic framework and established their identity as Isma'ilis within a larger Muslim ummah, with adherents pledging allegiance to the Aga Khan (Asani 2011; Steinberg 2011; Bolander 2016). The migration of Isma'ilis from India to East Africa in the late 19th/early 20th century, in pursuit of economic opportunities,

\footnotetext{
${ }^{1}$ The Isma'ili community underwent further succession crises. It is the largest denomination of these, the Nizari branch, that is the focus of this paper. For simplicity, all reference to Isma'ili will be referring to this denomination.
} 
represented another major migratory episode for the community. In East Africa, the Isma'ilis heeded the modernising agenda of Aga Khans III and IV - occupying a "middle sphere" between colonial and local customs and traditions whilst retaining cultural norms in a religious context and succeeding economically through improvements in education and social welfare (Mawani 2006; Versi 2010; Asani 2011). The 1972 Ugandan crisis, in which Idi Amin expelled all Asians from the country, caused a community upheaval. Isma'ilis in neighbouring East African states took this as an opportunity to migrate to other countries, primarily Britain and Canada. Isma'ilis in these countries were instructed by Aga Khan IV to make these countries their "home". The identities and experiences of these East African Isma'ilis have been extensively documented (e.g. Nanji 1983, 1986; Mukadam and Mawani 2006, 2009; Versi 2010). The fall of the Soviet Union in 1991 exposed Isma'ilis in the West to their coreligionists in Central Asia, in addition to those in Syria and Iran (Asani 2011). The encounter of these co-religionists, with their differing traditions and practices in relation to Isma'ilism, led the community to take on a more multi-ethnic identity under the ethos of "frontierless brotherhood". Institutional agencies such as The Institute of Isma'ili Studies and the Aga Khan Development Network facilitated a coming together and resource generation/capacity-building of Isma'ilis from different backgrounds to promulgate this sense of global identity with the central tenet of adherence to the Imam (Asani 2011; Steinberg 2011). The Golden Jubilee of Aga Khan IV in 2007-2008 fostered a sense of a global Isma'ili identity with events and festivals around the world. The creation of the Global Centre for Pluralism in Canada, and the Delegations of Isma'ili Imamat in Canada and Portugal, helped to physicalize the presence of a global Isma'ili community that is considered transnational and pluralistic.

\section{Australian Isma'ilis and their organisational structure}

As part of the diaspora from East Africa, many East African Isma'ilis also relocated to Australia, primarily to Perth and Sydney. The visit of Aga Khan IV in 1979 flagged Australia as a country of opportunity and, as more Isma'ilis migrated, the community expanded to Melbourne, Adelaide, and Brisbane. Today, the community is largely comprised of those South Asian families from East Africa and recent migrants directly from the subcontinent. In contrast to their counterparts in other Western countries, however, the Isma'ili population in Australia never really established itself and to date there are only approximately 2000 Isma'ilis scattered across five Australian cities.

Wherever Isma'ilis have migrated, the jamaatkhana ${ }^{2}$ has served as the central hub, a physical manifestation of continuity of religious identity and a space to establish community-based institutions known as the Councils. The Isma'ili Councils are community-based institutions that look after the social, educational, health, economic, and cultural needs of the community, while religious needs are addressed by the jamaatkhana and religious education boards (Asani 2011; Nanji 1983; Bolander 2016). The Councils serve a dual function of institutionalising community space and fostering community cohesion whilst following the guidance and policies of the Imam pursuant to that specific

\footnotetext{
${ }^{2}$ lit., 'the house of the community'. It refers to a place for congregational prayers and communal gatherings for Shi'a Imami Isma'ili Muslims.
} 
context (Nanji 1983). They are governed under the Isma'ili Constitution and this framework has enabled them to construct a sense of community and to promote social and economic progress (Ross-Sheriff and Nanji 1991). Generally, countries with a substantial Isma'ili population have a local Isma'ili National Council which operates independently to govern community affairs. Smaller jamaats (congregations) in other countries have their affairs managed by a larger National Council in another similar country, i.e.: jamaats in Angola and Mozambique fall under the jurisdiction of the Isma'ili Council for Portugal. The jamaat in Australia was previously under the jurisdiction of the Isma'ili Council for the USA; however, it has recently been able to attain its own National Council. This change enables the community to address its own local needs, including the growing and substantive youth population, which is in line with Muslim demographics overall in Australia (Hassan 2015). While the nascent Isma'ili Council for Australia also governs Isma'ili communities in New Zealand and Papua New Guinea, this paper solely examines Isma'ilis in Australia due to the emergence of two distinct "groups" of South Asians within the Australian Isma'ili collective: those who have emigrated directly from the subcontinent (the "diasporic") and those with ancestral links (the "post-diasporic"). This offers an opportunity to examine how religious identities are constructed amongst communities originally from the same background but with different migratory histories.

\section{Identity process theory}

This paper draws upon identity process theory (IPT) (Breakwell 1986; Jaspal and Breakwell 2014) to explore the construction, maintenance and protection of identity amongst Australian Isma'ilis. According to IPT, two universal processes guide identity construction: the accommodation-assimilation process, referring to the absorption of new information into the identity structure, and the evaluation process, which assigns meaning and value to identity contents (Breakwell 1986, 2001). These processes are guided by four principles: continuity, distinctiveness, self-efficacy, and self-esteem (Breakwell 1986, 2001). The theory has been extended by Vignoles et al. (2006) and Jaspal and Cinnirella (2010b) to include the principles of belonging, meaning, and psychological coherence. The theory postulates that when identity processes are unable to comply with these principles due, for instance, to changes in the social context, identity is threatened. For instance, in the context of this study, if Indian or Pakistani identity were to be stigmatised in Australian Isma'ili culture, this could result in decreased levels of selfesteem amongst individuals who self-identify as Indian or Pakistani, thereby inducing a threat to identity. According to IPT, the individual will then deploy strategies for coping with the threat to identity. Coping strategies can function at intra-psychic, interpersonal, or intergroup levels (Jaspal and Cinnirella 2010a). This paper considers identity processes, threat and coping among Australian Isma'ili Muslims in a context of structural changes to their self-governance and amid newer waves of Isma'ili migration to their existing community.

\section{Methods}

Participants were recruited from two Australian cities with the largest Isma'ili populations. A total of 15 individuals, 8 men and 7 women, were recruited for an interview 
study using a purposive sampling strategy. Respondents were categorized by immigration status (diasporic and post-diasporic), resulting in five respondents in each category, for a total of 10 youth respondents aged 18-25. Five members of the community leadership also participated in the interview study. The recruitment of a diverse sample of Australian Isma'ilis facilitated a holistic empirical snapshot of this under-explored community, as well as the consideration of a wide range of identity issues that may be relevant to it. The qualitative paradigm allowed for a richer understanding of social processes, meanings, and experiences of how these individuals construct their social and psychological worlds (Denzin and Lincoln 1998; Green and Thorogood 2013; Mays and Pope 2000).

Individual semi-structured interviews were conducted with respondents. The interview schedule focused on the migration patterns and history of Isma'ilis in Australia, their experiences, challenges, and meanings they attached to their ethno-cultural heritage, and their interactions with community members within and outside of the Australian Isma'ili context. Explanatory prompts were used to enable participants to elaborate on their responses. Interviews took place in a setting convenient for participants, and nearly all chose to be interviewed in the local jamaatkana. Informed oral and written consent was obtained prior to interviews. Interviews ranged from thirty minutes to three hours and were audio-recorded and later transcribed verbatim. Participants' real names have been replaced by pseudonyms.

Data were analysed using qualitative inductive thematic analysis which is 'a method for identifying, analysing and reporting patterns (themes) within data' (Braun and Clarke 2006:79). This approach enables the researcher to examine participants' accounts and to identify common codes and overarching themes using relevant theoretical concepts. The first author read the transcripts in detail, making annotations where appropriate, in order to familiarise himself with the data. During each reading of the transcripts, preliminary interpretations were noted in the left margin. These included inter alia participants' meaning-making, particular forms of language, and apparent contradictions and patterns. Initial codes aimed to capture, from the analyst's perspective, participants' attempts to make sense of the object of analysis. Then, the right margin was used to collate these initial codes into potential themes, which captured the essential qualities of the accounts. The list of themes was reviewed rigorously against the data to ensure their compatibility and numerous interview extracts were listed against each corresponding theme. At this stage, specific interview extracts, which were considered representative of the themes, were selected for presentation in this article. Finally, three superordinate themes reflecting the analysis were developed and ordered into a coherent narrative structure. In the quotes presented below, ellipses indicate that additional material from the respondents' own narrative account has been omitted for a streamlined response, whereas material in square brackets is for clarification.

\section{Findings}

In this section, the following three themes are outlined and described: (1) Challenges of maintaining an "Isma'ili" identity, (2) Two cultures, one identity: Reformulation of Australian Isma'ili Identity, and (3) Distinctiveness as isolating or empowering. 


\section{Challenges of maintaining an "Isma'ili" identity}

There appeared to be a generational difference regarding perceived attachment to an "Isma'ili identity". The community leadership expressed their concern that Australianborn Isma'ilis may not have a strong sense of attachment to their Isma'ili identity. For instance, Qayim, a community leader, reflected that while the youth may exhibit traits of spiritualistic practice, he worried that "their connection to the psyche of the jamaat may not be as strong" and "it saddens me... to think they don't... have the same notion of the Imam as I do". Zarin, another community leader, indicated that she worried of a "lost generation" - of not coming "to khane, ${ }^{3}$ not [being] involved in seva [voluntary service]...not connected to the jamaat in any way". For the community leaders, having undergone the migration process themselves, the jamaatkhana and the Imam played important roles in the establishment of their Isma'ili identity - both as a religious identity and as the principal connection they retained to their ethno-cultural tradition (Mawani 2006). It may, therefore, be important for community leaders to impart these symbolic links of continuity.

Despite this perception from the leadership, youths appeared actively involved in establishing meaning regarding their religious identity. For instance, Faisal, a diasporic youth, said they are "fortunate [as] Isma'ilis [as] we have a living Imam who guides us in every single way possible... whatever I am today is based on that guidance and that religion". This suggests that the Imam plays a crucial role in youth's confidence in their faith and in their articulation of it. Samir, a post-diasporic youth, stated that he felt that young Isma'ilis were not questioning "for the sake of questioning...but for the sake of knowledge, to understand the reason ...behind certain rituals and certain traditions". This indicates that youths are eager to understand the contextual meanings of their religious practice. This is in contrast to Mawani's (2006) finding that young Isma'ilis in Toronto imbue religious practices with meaning by re-constructing them as a symbolic component of community identity despite not necessarily knowing the function and intended meanings of the practices themselves.

For Isma'ili youth in Australia, their religious faith comprised an essential part of their identity. Some manifested its importance by participating in the congregational environment whilst others did so through personal acts of faith. For instance, Faisal said "mashallah, ${ }^{4}$ in these last three years I [have] come to $J K^{5}$ every day". Qayim also stated that he noticed small acts of worship amongst his own children; for instance, 'they say, 'I have an exam. Pray for me.' ....or before they go to bed they might say a short tasbih "." These two examples demonstrate that youth draw upon aspects of their faith in their daily lives. By proclaiming mashallah in response to his ability to go to jamaatkhana, Faisal saw this as a form of success. Qayim's remark that his children asked him to pray for them and that they took a tasbih indicated his pride, on the one hand, and also the fact that youths themselves incorporate small acts of worship into their daily lives. This can provide a sense of meaning, pride, and self-worth. Moreover,

\footnotetext{
${ }^{3}$ Colloq. jamaatkhana

${ }^{4}$ Lit., "God has willed it", often used in an appreciative/commendation context when recognizing the influence of God in that action

5 colloq. Jamaatkhana

${ }^{6}$ acts of remembrance of God
} 
this can enhance the meaning principle of identity - in this case, the living Imam and his guidance play a key role in establishing meaning in a context where it may otherwise be lacking. Faisal's earlier assertion that "whatever I am today is based on that guidance" suggests that in an ever-changing world, for Isma'ilis, the Imam is seen as facilitating sense-making through his ability to interpret the Islamic faith for his adherents across time and space. Thus, he is perceived as facilitating a sense of continuity between past, present and future.

Whilst members of the community leadership believe that Isma'ili youth have low affiliation to their community and to the Imam, young people conversely affirm their affiliation to their ethno-religious community as well as the role of the Imam in their lives. This is different for Isma'ilis vis-à-vis other Muslim communities for whom the onus is on the individual to utilise deductive reasoning from religious texts or community leaders delivering fatwas rather than from a living Imam who is said to constitute a temporal and spiritual link directly to the Prophet Muhammad. Asani (2011) suggests that this individual deductive reasoning leads to favouring orthopraxy, in which ritual is favoured over 'aql (intellect), and in revivalist Islamist tendencies the notion of adapting the faith to the time is seen negatively as bida' (innovation). Nevertheless, for Isma'ilis, the centrality of the Imam and his role in adapting the faith to modern times is suggested to play a central role in the community's integrative strategy in Canada and Britain (Versi 2010; Ross-Sheriff and Nanji 1991; Steinberg 2011; Mukadam and Mawani 2009). Central to establishing a firm religious identity, however, is the importance of having a strong foundation of religious knowledge - and this was a theme that emerged in the interview data.

\section{Religious education as a foundation for religious identity}

Religious education was seen as important, but lacking, in the Australian Isma'ili context. For example, Faisal said that in his home country, he "attended REC (religious education centre) for 10-11 years which strengthened those foundations". Hassan, a diasporic youth, described how in Pakistan "as a kid you do JK things as part of your life...you have to go to REC after school, three hours of REC every day MondayFriday, people enjoy it". He contrasted this experience to those of individuals born in Australia by stating that in Australia.

"there were a couple of kids who wouldn't come... [saying] they don't like it and it's not fun...they [the community leaders] looked into the issue and it turns out the teachers don't know the culture well, cuz they were recent immigrants so [they were] still Indian rather than Australian and thus [had] no connection [to the kids from here]".

This suggests a dichotomy in the way that diasporic and post-diasporic youth approach religious education. For Isma'ilis in Australia, REC is seen as supplemental and generally takes place for a few hours on a weekend, compared to India and Pakistan where it takes place, as Hassan says, "after school.every day". This difference in emphasis towards religious education can lead to challenges in the development of religious identity among Australian-born youth vis-à-vis those in other contexts. Qayim noted that Australian-born youths "do not know...enough about their own history, their 
own culture, their own faith". The small and formerly impermanent nature of the Isma'ili community in Australia may have impeded the ability to develop strong religious education foundations for Australian-born Isma'ili youth. Samir suggested that Australian-born youth.

" do not have that foundation...don't understand the rituals and traditions that happen in jamaatkhana, so it's more of a mechanical thing than understanding what is going on in khane. So there's no sense of attachment".

For Rabia, an Australian-born Isma'ili, her experience with REC could initially be seen as a threat to her religious identity but her own actions resulted in this being a strength:

"there are people from Pakistan... and they have this mad knowledge of our religion...whereas with me...religious education was a challenge here, so when I grew up and started teaching now I feel like I'm learning as I'm teaching...I didn't get the right religious education and I feel like these kids should and that's why I'm teaching".

Rabia's account outlines her perception of growing up as an Isma'ili without feeling sufficiently grounded in her religio-cultural tradition. Moreover, when she encountered newer migrants with a perceived greater knowledge of their faith, she appeared to experience a threat to her established identity. Breakwell (1986) suggests that in response to identity threats, individuals will employ various coping strategies. Thus, in response to threats to self-efficacy, Rabia sought to re-establish her sense of Isma'ili identity by engaging in activities to increase her religious competence. In providing religious education, she herself acts as both learner and teacher, and actively crafts her own identity as well as that of young Isma'ilis.

The sense of ascribing importance to religion as part of one's identity demonstrates the evaluation process of identity, as well as the attribution of meaning to one's life (Baumeister 1991). In the Australian context, it was evident that religious education played an important role in strengthening religious identity. In this case, the arrival of newer immigrants with a perceived greater religious knowledge base presented the post-diasporic youth with threats to identity as it highlighted the perceived deficiency of their own religious knowledge. This led them to question their own authenticity and self-confidence as Isma'ilis as they felt inferior due to their perceived limited knowledge concerning religious matters. However, an identity-enhancing strategy, as employed by Rabia, was to impart religious education herself - both as a means of influencing others' identity, and as a vehicle for further developing one's own identity. It is to this reformulation of identity, and the impact that the influx of recent migrants has had on its construction, that we now turn.

\section{Two cultures, one identity: reformulation of Australian Isma'ili identity}

As indicated earlier in this article, from the 1970s onward the Australian Isma'ili community was primarily composed of East Africans of South Asian descent. In this context, a nascent Australian Isma'ili identity developed under the steerage of the Isma'ili Council for the USA. The jamaat struggled with developing a unique sense of 
self given its transient settlement. The community has recently experienced an influx of migrants directly from South Asia, which, in the framework of IPT, represents an outgroup whose customs and traditions may be seen as foreign to the extant Isma'ilis. Indeed, in the context of religious identity and education, their differing practices serve as a clear demarcation of boundaries and identities - effectively acting as a de facto outgroup within a (nominal) superordinate ingroup. This may cause the extant community to feel insecure about their identities. In effect, the presence of the migrant community can pose threats to identity in the extant Isma'ili community, engendering doubts surrounding authenticity, legitimacy, and integration.

The tension of cross-cultural integration of different Isma'ili ethnic communities has been discussed by Mawani (2006), who recounts how the extant East African Isma'ili collective in Canada, despite purporting to be proponents of the pluralistic aspect of Isma'ilism, experienced some initial trepidation in integrating and accommodating migrant Central Asian Isma'ilis and their customs. Whilst Steinberg (2011) has alluded to the construction of an ethno-cultural hegemony of the South Asian Isma'ili tradition over other ethno-cultural traditions in Isma'ilism, this may actually reflect the East African community members and their traditions, who, by virtue of having undergone the initial migration and modernising process, may see themselves as more "authentic". In the Australian context, while both "groups" trace their roots to South Asia, they have a differing sense of attachment to that context. This raises questions surrounding identity authenticity as well as the legitimacy of particular religious practices. This aspect of identity threat was discussed across generational and diasporic/post-diasporic contexts. For instance, Zarin stated that there are two distinct groups of youth:

"one...has grown up here all their life... and they have a discomfort with their identity as an Isma'ili Muslim. They do not have that spark, that love for the Imam, to be able to articulate their faith...they don't feel they have the grounding in terms of their knowledge. [Then ]you've got a group that has grown up overseas and have gone through great REC systems and....grounding of "I am a Shia Imami Isma'ili Muslim and this is what I believe"."

Zarin's quote points to the likelihood of identity threat amongst Australian-born Isma'ili youth, which may impact the psychological coherence principle of identity. Jaspal and Coyle (2009) suggest that when encountering identity threat, one coping strategy may be to denigrate the out-group and to heighten the principle of distinctiveness to increase authenticity and sense of self-esteem. In the Australian Isma'ili context, where both "groups" in fact share ethno-cultural commonalities, demarcation of the in-group/out-group may be less clear-cut. Zarin stated that initial cohesion was quite difficult for the older generation:

" us as the established jamaat being able to support people coming in.. so they feel they are a part of the jamaat. We went through a period... where there was an influx of people who have grown up in a different culture...have a different grounding of faith, of their relationship to the Imam...it creates friction between them and the established jamaat... if you are Indian or African, there are big frictions here. And [the] Africans are the established jamaat so they feel it is their jamaat... and so [some may] feel the loss of "my jamaat" and "this is not my jamaat". And I think because it [the jamaat] is small...it can be fixed." ... 
Here, Zarin described how the arrival of another group of individuals with a different tradition and "relationship to the Imam" caused some discomfort amongst the extant community members and disrupted their religious and communal identity. Nevertheless, Zarin also stated that the community's small population was a strength and helpful in promoting unity. Moreover, Zarin indicated that the efforts of the community's leadership and insights from integrating Central Asian Isma'ilis into a largely East African community in Canada were instrumental for integrating and accommodating the migrant group into the extant Australian context.

Interestingly, despite Zarin's observation of frictions amongst the East Africans and the recent South Asian migrants, the post-diasporic youth did not agree with that narrative. Shumaila, a post-diasporic youth, stated that "recently, we've actually become friends with people who aren't born here. We've drawn them into youth programmes". This quote exemplifies the view of Australian-born youth concerning their relationships with the recent immigrants. This suggests that, rather than perceiving new immigrants as an identity threat, these youths have adopted an accommodating strategy based on belongingness, perhaps due to the premise of an "imagined" transnational community of Isma'ilis (see Anderson 1991). This is also consistent with Jaspal and Cinnirella's (2012) hypothesis that individuals who lack characteristics normally deemed to be important for inclusion in an in-group will de-emphasize these characteristics to enhance the belongingness principle. For Australian Isma'ili youth, incorporating the new migrants into their social networks suggests an active re-shaping of what it means to be an Australian Isma'ili. This may be different from what the first-generation immigrants perceive it to be. Whilst the latter may construe Isma'ili identity in ethnocultural terms, for Isma'ili youth, a more transnational religious identity took on greater importance. This favouring of a transnational religious identity over an ethnic one was also seen by recent migrants themselves. For instance, Sadru, a diasporic youth, said: "they are not my relatives, they are not from Pakistan, they are Indians but [are] still in jamaatkhana. They know me....so they can help me...in terms of [being an] Isma'ili community friend".

Here, Sadru highlighted the construction of a distinctive superordinate Australian Isma'ili community cutting across nationalistic boundaries of being Indian/Pakistani and thereby creating a sense of belongingness. Sadru's statement that "they can help me... [as an] Isma'ili community friend" suggests that adhering to a transnational community identity facilitates the establishment of social networks and bonds in a new social context which may not have existed in his "home" context. This was echoed by Hassan:

"Isma'ilis coming [here] ... have it easier than everyone else. They don't have to face domestic/settling problems...they come to a place... where everyone is supportive, especially in JK..[asking] if you need help and they will do everything possible to help you" and goes on to say that "all the youth are connected to each other".

His assertion that "everyone is supportive" and that "all the youth are connected" suggests there is a sense of a collective Isma'ili identity. This accords with current research in the Australian and British contexts indicating that Muslim youths tend to favour adherence to a transnational religious identity over an ethno-cultural one (Jaspal and Cinnirella 2012; Wise and Ali 2008). 


\section{Opportunities for cohesion}

To promote an Australian Isma'ili community identity, the jamaat has held annual residential summer camps for youths. Qayim described the camps as a platform for youths to discuss relevant identity issues, to build a shared sense of identity and community, and to learn about their faith. Yasmin, a community leader, provided the following reflections on the camps:

"With the camps...it was really something. They [the youth] could bond and be a part of [a larger community].. then the camps stopped [for several years] and I think that affected a lot of youth".

The camps not only helped encourage community-building but also addressed concerns regarding poor levels of religious knowledge amongst Isma'ili youth. Although the camps were held once annually, they appeared to play a central role in the development of a communal identity. Sadru, echoing the views of the other youths, stated he appreciated the camps as they "addressed a lot of questions youth have... doesn't matter if you are from India, or Pakistan, or a local". This indicates the camps have been useful in engaging youth and in developing their self-efficacy, belongingness, and self-esteem in relation to their religious identity. Haji (2011) describes how, in the Canadian Isma'ili context, faith-based residential camps can act as a faith-enhancer and as a means of establishing social networks and of facilitating belonging. It is evident that the camps perform a similar function in the Australian context which is beneficial given the Australian Isma'ili community is a small population dispersed over a geographically vast area. Sadru's statement that "it doesn't matter if you are from India, or Pakistan or a local" suggest that the camps play a central role in unifying the youth into a collective, distinct, Australian Isma'ili community, and that the strong ethno-cultural identities apparent in the older generation may not be as prevalent among diasporic and post-diasporic youth.

Whilst the recent arrival of the South Asian immigrants could act as a form of identity threat for the resident Isma'ilis in Australia, the coping strategies employed by the youth focused on identity enhancement. In this instance, the sense of belonging to a transnational community seems to have overridden the need to be seen as distinct groups of Isma'ilis. The Australian- born youths' inclusion of new South Asian Isma'ili immigrants into their social worlds may also act to further enhance their own legitimacy as Isma'ilis, given their limited religious education knowledge and their geographic and social isolation from the global Isma'ili community.

\section{Distinctiveness as isolating or empowering}

There was evidence of the construction of a distinct Australian Isma'ili identity vis-àvis the global Isma'ili community/identity. Due to the relatively small Isma'ili population dispersed across the vast Australian geographical territory, the internal affairs of the Australian Isma'ili community were previously managed by the Isma'ili Council for the USA. Whilst the Australian Isma'ili community has recently been able to selfadminister its own internal affairs via its own National Council, respondents seemed uncertain as to whether this "independence" would increase isolation or empower the 
community. Members of the community leadership explained that historically the Australian Isma'ili community has been isolated. Many of them spoke about global Isma'ili initiatives and the commemorative events for the Golden Jubilee of Aga Khan IV from which Australian Isma'ilis felt isolated. Jaffer, a community leader, stated that:

"it was also felt that... around the Golden Jubilee ...there were big issues in terms of the jamaat feeling detached from the rest of the [Isma'ili] institutions...it wasn't we weren't allowed [to participate] but [we were] restricted in terms of cost and distance".

Qayim added that the Golden Jubilee initiatives were

"all foreign concepts to Australia and New Zealand, sadly...none of the Jubilee programmes touched Australia. We were not recipients of any of those programmes because it costs so much to bring it here...I can understand the cost factor but Australia was...not implicit in their [the Isma'ili Council for the USA] planning of those programmes. So what happened was Australia and New Zealand...it was not thought of, sadly".

Both Jaffer and Qayim allude to a threat to identity. Although they acknowledged cost and distance as limiting factors in bringing any initiative to a geographically isolated community, they indicated that these constraints led Australian Isma'ilis to feel detached from, and minimally involved in, the global Isma'ili community. Qayim explained that

"there's a whole heap of activities all over the world in our [Isma'ili] community, and there's a great deal of excitement...the[Aga Khan] museum in Toronto, the high profile [Isma'ili] centres being built everywhere. That generates the kind of enthusiasm one needs to get closer to the community.... that is not rife here."

Furthermore, Yasmin compared social programming in Australia to that in other jurisdictions:

"until now we basically got filtered messages....they received inspirational, motivational talks in JK about every new thing [but] we didn't get it....by the time we got it, enthusiasm was not as high because we didn't get that vision.... We felt isolated, not inspired. We didn't get wa'ezeens (preachers) coming in and talking to us. India, Pakistan, Canada get wa'ezeens. We didn't get it very muchmaybe once or twice a year if we were lucky".

Both Yasmin and Qayim contrasted the experience of the Australian Isma'ili community to that of Isma'ilis in other country contexts. Their examples suggested that, as the Australian Isma'ili community does not have access to the same level of religious and social programming as other Isma'ili communities, they may not perceive a strong connection with their Isma'ili identity. Yasmin succinctly stated that "We felt isolated, not inspired". Respondents also felt their cultural context was unique and often overlooked in programme delivery. Yasmin explained that 
"the culture is different and whatever [the Isma'ili Council for the United States of] America sent.... we had to redo it in a language that we can understand in Australia. That is what I mean by getting the culture of the country. The Americans didn't get it....here [in Australia] it is more laidback and we basically got a filtered version and we had to create our own thing. I must say, Australians are very creative...America and Australia, both are in English [but] when you read the language [of the materials] they send it's quite different. American language is high-powered stuff which we are not. Here, there is no sense of competition. [For] Americans it's 'I am the most important thing'. There's nothing like that in Australia and so people didn't buy into it [the materials being sent] very much. There is a big cultural difference...the problem was we had to do things that were not appropriate to this context. We just copied or imported.the inspiration was missing. There was no hitting at emotion, just doing and implementing what we were told."

In her account, Yasmin stated that, despite some shared characteristics (e.g. being English-speaking Isma'ili communities living in the West), the cultural and contextual distinctiveness of the Australian Isma'ili community meant that much of religioeducational material sent by the Isma'ili Council for the USA was inappropriate for the Australian context. Yasmin juxtaposed the highly competitive culture of America to the laidback lifestyle of Australia, highlighting the distinct nature of the Australian Isma'ili identity. Indeed, the perception that religious and social materials were contextually inappropriate could have increased the Australian Isma'ili community's feelings of isolation.

The feeling of distinctiveness was also expressed by the Isma'ili youth. Bilal, an Australian-born youth, articulated that

"Australia is really different. Our Isma'ili community in Australia is quite different from the US, Canada, and UK in that...I can only speak for maybe the years 21 and up...[the] majority of our close friends are people who are outside the community rather than within the community. You sort of see that changing now as the jamaat is getting bigger".

This quote clearly demonstrates that Australian Isma'ili youths perceive their identity as distinct from that of other, global, Isma'ili communities. Interestingly, whilst Samir stated that he felt more comfortable around those of his own religious background, Bilal indicated that "[the] majority of our close friends are people who are outside the community". This suggests that Australian Isma'ili youth may establish their dominant social networks outside their religious community although they may still perceive a sense of comfort and belongingness within it.

The creation of the Isma'ili Council for Australia was regarded as a positive development by the community. However, this also brought with it new sets of challenges. Zarin contemplated "how do we do our programming to meet our needs....our youth are different than the youth in Toronto and so now we have the opportunity to do it right". This suggests that there is an active reflection on the part of the community regarding how best to develop and deliver social programming. Zarin's statement that "now it is beneficiary driven. We purposefully use youth to help build 
capacity" highlighted a desire to outline the future of the Australian Isma'ili community using active agency based on local needs. Indeed, it was only after the establishment of their own National Council that the community was able to resume the youth camps, which had been terminated by the Isma'ili Council for the USA. The youths themselves recognised the power of self-governance and felt motivated to contribute. Rabia stated that

"since we've been [our own] National Council, ...it seems like people are really starting to get serious about events and stuff...we take responsibility, we make sure things are done on time, so I think it's getting better. I think because we've been given...responsibility to open up our own ideas instead of sort of following everything that America says, it's sort of put us in a good place because we actually put effort into the fact it's our own work".

Rabia's quote demonstrates a sense of empowerment. The youths feel that they now have an opportunity to be actively involved in issues pertinent to their own community. This development of agency can lead to a positive and distinctive Australian Isma'ili identity. Nevertheless, individuals were cognisant of the fact that they could face similar issues to those faced by their counterparts in other contexts. For example, Samir discussed the experience of having a wa'ezeen come in from America, "it was very good... and allowed for the al-wa'ezeens from the US to actually cater to our needs because they have similar circumstances in the US as well with the youth....there's a huge need here."

Whilst both the leadership and the youth felt that there was a distinct Australian Isma'ili identity, the construction and manifestation of this identity within the global Isma'ili community has been problematic. Logistical constraints, such as cost and distance, have limited the opportunity for engagement within the global Isma'ili network. When the jamaat was administered by the Isma'ili Council for the USA, they believed that the materials that were sent to them did not reflect their socio-cultural climate and, thus, acted as a threat to identity. On the one hand, there was a desire for belongingness, to be a part of the Isma'ili transnational community but, on the other hand, the distinctiveness of the Australian Isma'ili experience served to limit their involvement with other Isma'ilis. This echoes a key tenet of Optimal Distinctiveness Theory (Brewer 1991), namely that the principles of distinctiveness and belonging are in tension with one another and that individuals strive for a balance between them. In this instance, the community's isolation could pose a threat to the continuity and belongingness principles of their Isma'ili community and religious identity. The recent self-administration and distinct nature of the Australian Isma'ili experience may raise questions as to whether now they are, echoing from the lyrics of the Australian national anthem, "young and free" or "girt by sea", in terms of feeling empowered or isolated. Nevertheless, it was apparent that the Australian Isma'ilis have focused on how their distinctiveness has enabled agency. The ability to develop community programming to suit local needs and the resulting impact on the youth highlights the possible benefits for the self-efficacy and self-esteem principles of identity. Indeed, this has given community members, and its youth, a sense of empowerment, optimism for the future, and a greater sense of pride in their identity. The benefits for self-esteem and selfefficacy may be considerable. 


\section{Discussion}

This paper examined how religious identity is constructed within a small and geographically isolated religious community - the Australian Isma'ili Muslims. It examined the interplay of identity construction amongst community leaders and youth, and the implications of newer waves of migration for a largely heretofore mono-ethnic community. This study specifically examines the case of the Australian Isma'ili community using an IPT perspective with the implication that migrants directly from South Asia pose a form of identity threat to the extant East African Isma'ilis.

Most studies on the Isma'ilis have focused on liturgical and acculturative processes in the Euro-American context. Whilst the community's pluralistic and integrative strategy is said to have helped in terms of inter-community integration, Mawani (2006) suggests intra-community ethnic plurality may be difficult in practice, citing the example of Toronto where the singing of a Central Asian devotional hymn (in the place of a South Asian one) during a religious festival caused some discomfort amongst her respondents. Steinberg (2011) furthers this argument by suggesting that despite the community's ethnic diversity, there exists a hegemonic imposition of the South Asian tradition in the practice of the faith.

The experience of the migrant Isma'ili community is in contrast to other South Asian diasporic communities for whom the notion of "homeland" is said to be important to their identity experience (Jaspal 2011; Jaspal and Cinnirella 2012). As they formulated and re-formulated their identity during their migratory history, East African Isma'ilis, in particular, were instructed to de-emphasize "Asiatic patterns of existence" (Nanji 1983:152). Their ethno-cultural traditions were relegated to what Mukadam and Mawani (2009) term the "sacred sphere" - religio-cultural symbolism and practice. Other markers of identity (e.g. language, dress, cuisine) were de-emphasized in order to align their religious practice to the Imam's instruction that they make their new countries of residence their homes (Nanji 1983; Mawani 2006; Mukadam and Mawani 2009; Versi 2010). As such, in contrast to other diasporic South Asian and Muslim communities (Edmunds 2010; Jaspal 2011), the Isma'ili diaspora does not retain physical links to their ancestral homeland. The East African Isma'ilis were left to recreate their own Isma'ili identity through, as Meda (2013) phrases it, "imagination" - reinventing traditions and customs to give new meaning to their identity, thereby creating a symbolic identity. Thus, in the Australian Isma'ili context, the arrival of Isma'ilis directly from the subcontinent brought traditional values and attitudes with which East African Isma'ilis were unfamiliar. For the older generation, this could be perceived as a threat to their "modernity" given that East African Isma'ilis had largely assigned ethno-cultural practices to the sacred sphere. This is consistent with Ryan's (2014) observation that "modern" Muslims are less religious than those from "back home".

The possibility of identity threat was perceived differently by the leadership and the Australian-born youth. It centred around "authenticity" - with recent immigrants perceived to have a stronger religious education knowledge base and thus serving as a reference marker against which to compare the post-diasporic youth in terms of perceived lack of religious education knowledge and discomfort in Isma'ili identity. Jessa (2011) suggests that for young Canadian Isma'ilis religious education helped strengthen religious identity and helped establish a sense of community belonging. In the Australian context, despite the potential threat to the self-esteem and continuity 
principles that the new immigrants posed with their greater religious education knowledge base, post-diasporic youth utilised this situation as an opportunity to enhance their sense of self-efficacy. The questioning of faith and practices, perceived by the leadership to be demonstrative of insecure attachment to their faith identity, was actually seen by the youth as a means of better understanding their tradition. This is consistent with van Heelsum and Koomen (2016) observing that young Muslims in Western contexts strive to be more knowledgeable about their faith and employ a more critical stance on taken-for-granted aspects of it.

For Australian Isma'ili youth, who may have felt socially and geographically isolated from the global Isma'ili community, the arrival of the recent migrants physicalized the notion of Isma'ili Islam as a global community and thus enhanced their sense of belonging to their religious identity, accommodating these new immigrants into a communal identity based on transnationalism, showcasing the importance of the meaning and belongingness principles of IPT. For the recent immigrants, they found that, once in Australia, their previous nationalistic boundaries and identities (e.g. Indian, Pakistani) decreased in salience vis-à-vis a superordinate religious identity. They, too, appeared to attribute greater importance to their religious identity than to their ethno-cultural identity once in their new context. Valentine and Sporton (2009) argue, for diasporic and post-diasporic Muslims, belonging to a transnational entity offers a sense of "stable attachment". Whilst for the older generation, the construct of "Isma'ili-ness" may have been perhaps ethno-cultural, for Australian-born youths, who grew up as an ethno-religious minority in Australia and thus may have felt a disconnect from their parental ethno-cultural background, the physical manifestation of a transnational community represented by the arrival of the new immigrants may have helped to facilitate a stronger sense of belonging to a superordinate religious identity (Ysseldyk et al. 2010; Wise and Ali 2008).

Historically, Isma'ili identity has always been a pliable one and "has meant different things at different times and places" (Lewis 1967:138; Asani 2011). The current notion of a globalised Isma'ili identity has parallels to other Muslim communities. However, amongst Australian Isma'ilis, ethnic and religious identity do not appear to be conflated, as is often seen in other contexts (e.g. with British Pakistanis). In this context, the transnational element of Isma'ili identity takes primacy, and, when confronted with identity threat, this becomes malleable (Jaspal and Cinnirella 2010a). In the Australian context, Isma'ili youth seemed to challenge notions of authenticity by creating their own version of Australian Isma'ili identity. This parallels current patterns of Islamic revivalism where migrant Muslim communities, which were often stratified ethnoculturally, are now seen as amalgamating into a pan-Islamic ideology, albeit one that is largely based on orthopraxy (Asani 2011; Asmar 2001; Ryan 2014; Kibria 2008). Amongst diasporic Muslim communities, a more transnational Muslim identity is favoured, particularly amongst the younger generations, as it is considered more "authentic" than the Islamic identities of their parents which may be manifested in ethno-cultural terms. This could explain the revivalist notions of the "Islam over culture" movement and the desire to adhere to a globalised ummah (Ryan 2014).

For Australian Isma'ilis, their religious identity was further enhanced by their recent self-administration as a National Council, which provided a sense of empowerment and newfound confidence. Though previously being managed by the Isma'ili Council for the USA should have had the effect of increasing feelings of belongingness, of being part of a 
transnational community, respondents instead described the distinctiveness of the Australian Isma'ili identity. Indeed, respondents spoke of being limited recipients of religious and social programming, and the ones they did receive were not felt to be appropriate for their particular context. Additionally, the community found the youth camps to be important and spoke of how the cessation of these camps may have impacted the community's sense of cohesiveness and identity. Nevertheless, respondents spoke of how the geographic disparateness of the community in Australia was a unique point and showcased their skill set and strengths in being a unified community despite geographic boundaries. Moreover, the creation of their own National Council led to individuals feeling they could now better cater for their local needs, take responsibility, find a greater sense of involvement and speak to the larger, global, Isma'ili community in their distinctive Australian "voice". This emphasizes the importance of the self-efficacy and self-esteem principles - by finding social value and a sense of control, they are able to articulate and develop a greater sense of the Australian Isma'ili identity.

It was noteworthy that soon after the Isma'ili Council for Australia was officially created, some Australian Isma'ili youth went to study at The Institute of Isma'ili Studies, a research institute in London, UK, whose remit is the scholarship of Isma'ilism from a socio-historical and theological perspective within the larger framework of Shi' ism and Islam as a whole (Walker 2004). Steinberg (2011) argues that the existence of the Institute facilitates a physicality of the transnational community of Isma'ilis enabling Isma'ilis from different cultural contexts to interact whilst pursuing further scholarship of Islam. The programming run by the Institute is used as cross-cultural dialogue, human resources training, and producing, transforming, and re-producing a common sense of Isma'ilism (Steinberg 2011). The physical presence of Australian youth at the Institute can be construed as a sense of the community "being on the map", promoting empowerment, belongingness and a sense of continuity. It is also noteworthy that subsequently, researchers from the Institute also went to Australia to examine various aspects of the community there. The Institute of Isma'ili Studies is in discussion to bring the new Secondary Teacher Educator Programme, a religious educator teacher training programme for Isma'ilis globally, to Australia, and Australian youths have also competed at the global Isma'ili Jubilee Games sports tournament. This dialogical exchange can essentially be construed as a sense of external validation (Jaspal 2011) of the distinctiveness of the Australian Isma'ili community and their identity, thereby helping to mitigate any continual feelings of geographic and social isolation.

The importance of the jamaatkhana and the National Councils in promoting a sense of collective identity amongst Isma'ilis cannot be understated (Nanji 1983; Mawani 2006; Versi 2010). Whilst this study addressed the role of the new National Council structure, it did not examine the role of religious space in fostering a religious or social identity. The role of community centres and religious spaces in fostering community cohesion is important in South Asian diasporic populations (Ahmad et al. 2005; Oliffe et al. 2007). As a new jamaatkhana has been constructed in Melbourne to accommodate the growing Isma'ili population, it would be interesting to examine whether the construction of a permanent religious space ties into existing feelings of empowerment that were seen during the creation of a new Isma'ili National Council. Additionally, this study focused solely on youths who attended jamaatkhana and as such further studies could examine how youths who do not regularly attend congregational worship construct their religious identities. 
This paper has built on prior work examining Isma'ili diasporic communities (ie: Ross-Sheriff and Nanji 1991; Nanji 1983; Mawani 2006; Mukadam and Mawani 2006, 2009) and indeed work on South Asian and Muslim diasporic communities. It has also aimed to address hypotheses developed by Jaspal and Cinnirella (2012), namely that perceived belonging within a religious community can also enhance identity amongst diasporic South Asian youth. However, unlike Jaspal and Cinnirella's (2012) hypothesis, this study did not show any evidence of a hyphenated identity. Furthermore, postdiasporic individual youth did not choose to highlight their distinctiveness when encountering "indigenous" members from the ancestral homeland. Given the distinctive nature of Isma'ili Islam, the integrative strategies which they use in their new country contexts, and the disconnect Isma'ilis may feel from the larger Muslim ummah (Muhammedi 2010), further studies could examine how these individuals situate themselves vis-à-vis the larger Australian context and in the larger Muslim ummah.

Overall, despite the potential for identity threat of a group of recent migrants in a scattered, geographically, and socially isolated community, it appears that the extant Isma'ili community in Australia has chosen instead to embrace the arrival of youth from the Indian subcontinent. They viewed their arrival as an opportunity to further develop their Australian Isma'ili identity, balancing the pursuit of a distinctive identity with the search for global unity (Aga Khan 2008). The exploration of this small community has implications for other migrant Muslim communities. Specifically, the means by which the Australian Isma'ili youths have broken down barriers to accommodate individuals within a pan-Isma'ili identity has implications for Muslim communities in other Western contexts who may feel disenfranchised and alienated. For instance, further research could examine how other Muslim groups are manifesting and developing their identities when encountering Muslims from other contexts or indeed from other communities in terms of accommodating Muslim migrants into their collective sphere, and the implications for pan-Islamism, Islamic revivalism, and questions surrounding "legitimacy" over cultural practices of Islam.

Acknowledgements The corresponding author would like to thank Zuleikha Haji for her comments into an earlier draft of this paper and Sharmina Mawani for her insights into Ismai'li youth identity.

\section{Compliance with ethical standards}

Funding and conflict of interest This study was supported by a travel grant from The Institute of Ismaili Studies. There are no other known potential conflicts of interest.

Open Access This article is distributed under the terms of the Creative Commons Attribution 4.0 International License (http://creativecommons.org/licenses/by/4.0/), which permits unrestricted use, distribution, and reproduction in any medium, provided you give appropriate credit to the original author(s) and the source, provide a link to the Creative Commons license, and indicate if changes were made.

\section{References}

Aga Khan IV (2008). “The Peterson Lecture" by His Highness the Aga Khan to the Annual Meeting of the International Baccalaureate, marking its 40th Anniversary. http://www.akdn.org/Content/637/AnnualMeeting-of-the-International-Baccalaureate. Accessed 10 April 2016. 
Ahmad, F., Cameron, J. I., \& Stewart, D. E. (2005). A tailored intervention to promote breast cancer screening among South Asian immigrant women. Social Science and Medicine, 60, 575-586.

Anderson, B. (1991). Imagined communities: reflection on the origin and spread of nationalism - revised edition. London: Verso.

Asani, A. (2011). From Satpanthi to Ismaili Muslim: the articulation of Ismaili Khoja identity in South Asia. In F. Daftary (Ed.), A modern history of the Ismailis: continuity and change in a Muslim community (pp. 95128). London: I.B. Tauris.

Asmar, C. (2001). A community on campus: Muslim students in Australian University. In A. Saeed \& S. Akbarzadeh (Eds.), Muslim communities in Australia (pp. 138-160). Sydney: UNSW Press.

Baumeister, R. F. (1991). Meanings of life. New York: Guilford.

Bolander, B. (2016). English and the transnational Ismaili Muslim community: identity, the Aga Khan, and infrastructure. Language in Society, 45(4), 583-604.

Braun, V., \& Clarke, V. (2006). Using thematic analysis in psychology. Qualitative Research in Psychology, 3(2), 77-101.

Breakwell, G. M. (1986). Coping with threatened identities. London: Methuen.

Breakwell, G. M. (2001). Social representational constraints upon identity processes. In K. Deux \& G. Philogene (Eds.), Representions of the social: bridging theoretical traditions (pp. 271-284). Oxford: Blackwell.

Brewer, M. B. (1991). The social self: on being the same and different at the same time. Personality and Social Psychology Bulletin, 17, 475.482.

Cayo, D. (2008, November 28). Q and A with the Aga Khan. Vancouver Sun. http://www.canada. com/vancouversun/story.html?id=91ebc3d8-e662-43dd-98ef-030a803f33b1. Accessed 12 Feb 2013.

Daftary, F. (1998). A short history of the Ismailis: traditions of a Muslim community. Edinburgh: Edinburgh University Press.

Denzin, N.K. \& Lincoln, Y.S. (1998). Introduction: entering the field of qualitative inquiry. In N. K. Denzin \& Y. S. Lincoln (Eds.), Handbook of qualitative research (pp. 1-17). Thousand Oaks: Sage Publications.

Edmunds, J. (2010). 'Elite' young Muslims in Britain: From transnational to global politics. Contemporary Islam, 4(2), 215-238.

Green, J., \& Thorogood, N. (2013). Qualitative methods for Health Research. London: Sage Publications.

Haji, Z. (2011). The role of the curriculum as a mediating agency at Horizons Al-Ummah camp in Canada. Unpublished Master's dissertation: The Institute of Isma'ili Studies, London.

Hassan, R. (2015). Australian Muslims: a demographic, social, and economic profile of Muslims in Australia, 2015. Adelaide: International Centre for Muslim and non-Muslim Understandings, University of South Australia.

van Heelsum, A., \& Koomen, M. (2016). Ascription and identity. Differences between first-and secondgeneration Moroccans in the way ascription influences religious, national and ethnic group identification. Journal of Ethnic and Migration Studies, 42(2), 277-291.

Jaspal, R. (2011). The construction and management of ethnic identities among British south Asians: an identity process theory approach. Royal Holloway, University of London: Unpublished Doctoral dissertation.

Jaspal, R., \& Breakwell, G. M. (Eds.). (2014). Identity process theory: Identity, social action and social change. Cambridge: Cambridge University Press.

Jaspal, R., \& Cinnirella, M. (2012). The construction of ethnic identity: Insights from identity process theory. Ethnicities, 12(5), 503-530.

Jaspal, R., \& Cinnirella, M. (2010a). Media representations of British Muslims and hybridised threats to identity. Contemporary Islam: Dynamics of Muslim life, 4(3), 289-310.

Jaspal, R., \& Cinnirella, M. (2010b). Coping with potentially incompatible identities: Accounts of religious, ethnic, and sexual identities from British Pakistani men who identify as Muslim and gay. British Journal of Social Psychology, 49(4), 849-870.

Jaspal, R., \& Coyle, A. (2009). Language and perceptions of identity threat. Psychology and Society, 2(2), $150-167$.

Jessa, R. (2011). Negotiating multiple identities: Canadian Ismaili Muslim youth in Vancouver. The Institute of Ismaili Studies, London: Unpublished Master's dissertation.

Kibria, N. (2008). The 'new' Islam and Bangladeshi youth in Britain and the US. Ethnic and Racial Studies, 31(2), 243-266.

Lewis, B. (1967). The assassins: a radical sect in Islam. London: Weidenfeld and Nicolson.

Mawani, S. (2006). The construction of identities amongst young Nizari Ismaili Muslims in Toronto and Mumbai. School of Oriental and African Studies, London: Unpublished Doctoral dissertation.

Mays, N., \& Pope, C. (2000). Qualitative research in health care: assessing qualitative research. British Medical Journal, 320(7226), 50-52. 
Meda, S. (2013). Transnational identities: a preliminary exploratory study on the transnational socialisation of second-generation Egyptian adolescents in Italy. Italian Journal of Sociology of Education, 5(3), 62-88.

Muhammedi, R. (2010). Canadian Ismaili Muslim youth: Issues of identity and value association. The Insitute of Ismaili Studies, London: Unpublished Master's dissertation.

Mukadam, A., \& Mawani, S. (2006). Post-diasporic Indian communities: a new generation. In S. Coleman \& P. Collins (Eds.), Locating the field: metaphors of space, place and context in anthropology (pp. 105129). London: Berg Publishers.

Mukadam, A., \& Mawani, S. (2009). Excess baggage or precious gems? The migration of cultural commodities. In P. Hopkins \& R. Gale (Eds.), Muslims in Britain: race, place, identities (pp. 150-168). Edinburgh: Edinburgh University Press.

Nanji, A. (1983). The Nizari Ismaili Muslim community in North America: background and development. In E. H. Waugh, B. Abu-Laban, \& R. B. Quereshi (Eds.), The Muslim community in North America (pp. 149-164). Edmonton: The University of Alberta Press.

Nanji, A. (1986). The Ismaili Muslim identity and changing contexts. In V. C. Hayes (Ed.), Identity issues and world religions (pp. 119-124). Bedford Park: Australian Association for Study of Religions.

Oliffe, J. L., Grewal, S., Bottorff, J. L., Luke, H., \& Toor, H. (2007). Elderly South Asian Canadian immigrant men: Confirming and disrupting dominant discourses about masculinity and men's health. Family \& Community Health, 20, 224-236.

Ross-Sheriff, F., \& Nanji, A. (1991). Islamic identity, family, and community: the case of the Nizari Ismaili Muslims. In E. H. Waugh, S. M. Abu-Laban, \& R. B. Qureshi (Eds.), Muslim families in North America (pp. 101-117). Edmonton: University of Alberta Press.

Ryan, L. (2014). 'Islam does not change': young people narrating negotiations of religion and identity. Journal of Youth Studies, 17(4), 446-460.

Steinberg, J. (2011). Isma'ili modern: globalization and identity in a Muslim community. Chapel Hill: The University of North Carolina Press.

Valentine, G., \& Sporton, D. (2009). How other people see you it's like nothing that's inside: the impact of processes of dis-identification and disavowal on young people's subjectivities. Sociology, 43(4), 735-751.

Versi, S. (2010). Make this your home: The impact of religion on acculturation: The case of the Canadian Khoja Nizari Isma'ilis from East Africa. Unpublished Master's dissertation: Queen's University, Canada.

Vignoles, V. L., Regalia, C., Manzi, C., Golledge, J., \& Scabini, E. (2006). Beyond self esteem: Influence of multiple motives on identity construction. Journal of Personality and Social Psychology, 90(2), 308-333.

Walker, P. E. (2004). Institute of Ismaili Studies. In E. Yarshater (Ed.), Encyclopaedia iranica, Vol XIII. New York. Columbia University.

Wise, A., \& Ali, J. (2008). Muslim-Australians and local government: Grassroots strategies to improve relations between Muslim and non-Muslim-Australians: Final research report. Sydney: Centre for Research on Social Inclusion.

Ysseldyk, R., Matheson, K., \& Anisman, H. (2010). Religiosity as identity: toward a understanding of religion from a social identity perspective. Personality and Social Psychology Review, 14(1), 60-71. 